\title{
Uji Efektivitas Antijamur Kitosan Cangkang Kepiting Bakau (Scylla sp) Terhadap Pertumbuhan Epidermophyton floccosum dan Candida albicans
}

\author{
Suherman Baharuddin. ${ }^{\mathrm{a}, 1^{*}}$ \\ ${ }^{a}$ Farmasi Universitas Indonesia Timut, Makassar, Sulawesi Selatan, 90222 \\ ${ }^{1}$ ince.suherman81@gmail.com* \\ *korespondensi penulis
}

\begin{tabular}{ll}
\hline INFO ARTIKEL & ABSTRAK \\
\hline $\begin{array}{l}\text { Sejarah artikel: } \\
\text { Diterima }\end{array}$ & $\begin{array}{l}\text { Kitosan dan turunannya telah banyak dimanfaatkan dalam berbagai bidang misalnya } \\
\text { dalam bidang pangan, mikrobiologi, pertanian farmasi, dan sebagainya. Kitosan memiliki } \\
\text { Revisi }\end{array}$ \\
Difat antimikroba, karena dapat menghambat bakteri patogen dan mikroorganisme \\
pembusuk, termasuk jamur, bakteri gram-positif, bakteri gram negatif. Tujuan dari \\
penelitian untuk mengetahui efektivitas antijamur kitosan cangkang kepiting bakau (Scylla
\end{tabular}

Key word:

Effectiveness;

Antifungal;

Chitosan;

Epidermophyton

floccosum;

Candida albicans.

\section{ABSTRACT}

Chitosan and its derivatives have been widely used in various fields, for example in the fields of food, microbiology, agriculture, pharmacy, and so on. Chitosan has antimicrobial properties, because it can inhibit pathogenic bacteria and spoilage microorganisms, including fungi, gram-positive bacteria, and gram-negative bacteria. The purpose of this study was to determine the antifungal effectiveness of mangrove crab shell chitosan (Scylla $\mathrm{sp}$ ) on the growth of $E$. floccosum and $C$. albicans and to determine the most effective concentration. The isolation methods used included deproteination, demineralization, depigmentation, and 3-step deacetylation. The antifungal effectiveness test was carried out by disc diffusion method (Kirby-Bauer test) using disc paper. The results showed that the results of the isolation of chitosan from mud crab shells through several stages were 46.3 g. The antifungal effectiveness of mangrove crab shell chitosan ( $S_{c y}$ lla sp) on the growth of E. floccosum and C. albicans at incubation periods of $3 \times 24$ hours and $4 \times 24$ hours showed that the higher the concentration of chitosan, the greater the zone of inhibition (effectiveness) obtained. The most effective concentration was in the concentration range of $5 \% \mathrm{w} / \mathrm{v}$ (oneway ANOVA, $=0.05$ ), where the inhibition of E. floccosum was $16,23 \pm 0,64 \mathrm{~mm}$ for $3 \times 24$ hours and $17,56 \pm 0,75 \mathrm{~mm}$ for $4 \times 24$ hours. While the inhibition of $C$. albicans for $3 \times 24$ hours was $13,56 \pm 0,49 \mathrm{~mm}$ and $14,10 \pm 0,17 \mathrm{~mm}$ for 4 x 24 hours.

This is an open access article under the CC-BY-SA license. 


\section{Pendahuluan}

Kitosan sangat berpotensi untuk dijadikan sebagai bahan antimikroba, karena mengandung enzim lisozim dan gugus aminopolisakarida yang dapat menghambat pertumbuhan mikroba. Enzim lisozim merupakan enzim yang sanggup mencerna dinding sel bakteri sehingga bakteri akan kehilangan kemampuannya menimbulkan penyakit dalam tubuh (hilangnya dinding sel ini menyebabkan sel bekteri akan mati). Kemampuan dalam menekan pertumbuhan bakteri disebabkan bahwa kitosan memiliki polikation bermuatan positif yang mampu menghambat pertumbuhan bakteri (Riski, et.al, 2015). Kitin dan kitosan memiliki kegunaan yang sangat luas dalam kehidupan sehari-hari misalnya sebagai adsorben limbah logam berat dan zat warna, pengawet, antijarnur, kosmetik, farmasi, flokulan, anti kanker, dan antibakteri (Pratiwi, 20I4).

Kitosan merupakan bahan bioaktif dan aktivitasnya dapat diaplikasikan dalam bidang perikanan, pertanian, lingkungan industri, kecantikan, farmasi, kesehatan, dan pangan. Kitosan memiliki sifat antimikroba, karena dapat menghambat bakteri patogen dan mikroorganisme pembusuk, termasuk jamur, bakteri gram positif, dan bakteri gram negatif (Damayanti, et.al, 2016). Kitosan adalah suatu polisakarida yang diperoleh dari hasil deasetilasi kitin. Pada umumnya kitosan dibuat dari limbah hasil industri perikanan, seperti udang, kepiting dan rajungan. Kitosan tersebut berasal dari bagian kepala, kulit ataupun karapas. Pengembangan aplikasi kitosan sangat potensial, karena jumlah produksi udang, kepiting dan rajungan yan terus meningkat (Rochima 2014).

Kepiting merupakan hewan invertebrata air yang berkulit keras (Crustacea) dan merupakan salah satu kekayaan alam yang berasal dari perairan Indonesia serta mengandung kitin secara berlimpah. Pemanfaatan berbagai jenis kepiting khususnya Kepiting Bakau (Scylla sp) umumnya baru terbatas untuk keperluan makanan, biasanya hanya dagingnya saja yang diambil sedangkan cangkangnya dibuang, padahal cangkang kepiting mengandung senyawa kitin yang cukup tinggi yaitu sekitar 70\% dari Crustacea lainya dan sekitar 20-30\% dari berat kulit keringnya sedangkan kulit kepiting sendiri merupakan limbah kepiting yang belum diolah secara maksimal (Kusuma, 2016).

Kepiting bakau (Scylla sp) merupakan salah satu komoditas perikanan yang hidup di perairan pantai, khususnya di hutan bakau (mangrove). Komunitas kepiting bakau cukup besar dibanding dengan kepiting rajungan; oleh karenanya Indonesia merupakan negara pengekpor kepiting bakau. Di samping itu tingginya protein cangkang kepiting bakau dari pada rajungan, akan mempengaruhi jumlah kitin yang diperoleh. Menurut Muzarelli dalam Suhardi (1993), kandungan kitin dalam cangkang kepiting sekitar 7I.4 \% (Sanjaya dan Yuanita, 2007).

Salah satu cara untuk mengurangi pencemaran lingkungan dari cangkang kepiting diolah menjadi sumber kitin untuk bahan baku pembuatan kitosan (Aji dan Meriatna, 2012). Kepiting mengandung persentase kitin paling tinggi $(70 \%)$ diantara bangsabangsa krustasea, insekta, cacing maupun fungi. Kitin yang terkandung inilah yang nantinya dideasetilasi menjadi kitosan (Trisnawati, et.al, 2013). Mekanisme yang mungkin terjadi yaitu molekul kitosan memiliki kemampuan untuk berinteraksi dengan senyawa pada permukaan sel bakteri ataupun jamur kemudian teradsorbsi membentuk semacam layer (lapisan) yang menghambat saluran transportasi sel sehingga sel mengalami kekurangan substansi untuk berkembang biak dan mengakibatkan matinya sel bakteri dan jamur (Azora, 20I3).

Jamur oportunistik yaitu fungi dengan daya virulensi yang sangat rendah, namun dapat menyebabkan infeksi dalam keadaan dimana kekebalan tubuh tidak berfungsi baik. Infeksi jamur oportunistik banyak disebabkan oleh kelompok cendawan Dermatofit dan Candida (Midgley et.al, 2008 ; Ratnawati, et.al, 2016). Sebagian besar infeksi oportunistik disebabkan oleh infeksi yang superficial atau infeksi cendawan pada kulit yang disebabkan oleh cendawan yang tergolong dermatofita (cendawan kulit) seperti Trichopyton sp, Epidermopyhton sp dan Microsporum sp. Sedangkan infeksi lainnya disebabkan oleh Candida, Malassezia furfur, Exophiala, Werneckill, Piedraiahortae dan Trichosporon cutaneum. Selain itu Infeksi cendawan juga banyak disebabkan oleh kelompok Candida seperti Candida albicans, Candida tropicalis dan Candida parasilofsis, umumnya bagian jaringan yang mengalami luka (Ratnawati, et.al, 2016).

Untuk meningkatkan efektifitas pengobatan infeksi jamur dan mengurangi resistensi serta efek samping sudah banyak dilakukan pengembangan penelitian dari bahan alam yang sifatnya sebagai obat tradisional, obat herbal dan ada pula yang dikembangkan dari bahan biopolymer merupakan hasil konversi (pengubahan) senyawa kitin melalui deasetilasi kitin dengan alkali kuat atau enzim kitin deasetilase yaitu kitosan.

Pada dasarnya penelitian tentang kitosan sudah banyak diterapkan diberbagai bidang salah satunya pada bidang mikrobiologi, dimana kitosan digunakan sebagai bahan antimikroorganisme. Beberapa penelitian sebelumnya yang telah dilakukan 
diantaranya kitosan kulit udang Vannemei (Litopenaeus vannamei) memiliki potensi sebagai antibakteri dalam menghambat pertumbuhan Staphylococccus epidermidis, Pseudomonas aeruginosa, Propionibacterium agnes, dan Escherichia coli (Suherman, et. al, 2018). Ada pula tentang penelitian kitosan cangkang kerang bulu memiliki aktivitas antibakteri terhadap Staphylococcus epidermidis dan Escherichia coli hasil isolat kultur pus (Baharuddin S. dan Isnaeni D. 2020). Penelitian lainnya yang dilakukan oleh Mawaddah, et.al. (20I4) menunjukkan bahwa Kitosan, Trichoderma sp. dan kombinasi kitosan dan Trichoderma sp. dapat efektif menghambat pertumbuhan koloni jamur $C$. gloeosporioides secara in vitro. Menurut Mulyaningtyas, et.al, (2016) juga mengemukakan bahwa KBMR dari kitosan komersial hasil hidrolisis oleh B. firmus E65 secara enzimatik, KBMR berukuran nano yang diperoleh dengan metode gelasi ionik berukuran 228,74 nm, serta perbandingan volume KBMR dan NaTPP 3:I yang paling efektif untuk menghambat pertumbuhan jamur $C$. gloeosporioides secara in vitro dan in vivo.

Berdasarkan uraian di atas serta berbagai penelitian tentang kitosan, maka perlu dilakukan penelitian mengenai uji efektivitas antijamur kitosan cangkang kepiting bakau (Scylla sp) terhadap pertumbuhan Epidermophyton floccosum dan Candida albicans dengan tujuan untuk mengetahui efektivitas antijamur kitosan cangkang kepiting bakau (Scylla sp) terhadap pertumbuhan Epidermophyton floccosum dan Candida albicans serta menentukan konsentrasi yang paling efektif.

\section{Metode}

Penelitian ini merupakan penelitian eksperimental yang dilakukan dengan menguji efektivitas antijamur kitosan cangkang kepiting bakau (Scylla sp) terhadap pertumbuhan Epidermophyton floccosum dan Candida albicans. Pengambilan sampel dilakukan didaerah kabupaten Bone Sulawesi Selatan. Pengolahan dan proses deproteinasi, demineralisasi, depigmentasi, dan deasetilasi dilakukan di Laboratorium Kimia Farmasi Universitas Indonesia Timur Makassar. Isolasi, identifikasi jamur dan pengujian efektivitas antijamur kitosan dilakukan di Laboratorium Mikrobiologi Farmasi Universitas Indonesia Timur Makassar.

\section{Alat dan Bahan}

Alat-alat yang digunakan dalam penelitian adalah Autoclave (Gea $24 \mathrm{~L}$ ), ayakan mesh 100 (ABM), batang pengaduk (IWAKI Pyrex), cawan petri (Anumbra), corong gelas (IWAKI Pyrex), erlenmeyer (IWAKI Pyrex), gelas ukur (IWAKI
Pyrex), gelas kimia (IWAKI Pyrex), jangka sorong (Mitotuyo 0-150), Laminar Air Flow (Esco), lumpang, labu ukur (IWAKI Pyrex), lampu spritus, ose bulat, oven (Memmert UN $5553 \mathrm{~L}$ ), penangas air (Faithful Model DK-2000-IIIL 6 Holes), pinset (GOOI TS-II), tabung reaksi (IWAKI Pyrex), rak tabung, stamper, sendok tanduk, timbangan analitik (AND GR-300), timbangan analog (PGB),

Bahan yang digunakan dalam adalah aluminium foil, aquabides (WaterOne), asam asetat (Merck), asam klorida (Merck), aseton (Merck), biakan Candida albicans, biakan Epidermophyton floccosum, cotton bud, kertas cakram (Macherey Nagel), Ketoconazole, kitosan hasil isolasi dari kepiting Bakau, kertas saring, natrium hidroksida (Merck), natrium klorida (Merck), natrium hipoklorit (Merck), Saboraud Dekstrosa Agar (SDA) (Merck)

\section{Jalannya Penelitian \\ Pengolahan Bahan Uji}

Kepiting Bakau yang didapat dari daerah kabupaten Bone selanjutnya diambil cangkangnya, kemudian cangkang dicuci dengan air dan dikeringkan di bawah sinar matahari. Selanjutnya bahan yang sudah kering ditumbuk dan diblender sampai menjadi serbuk dan diayak menggunakan ayakan 100 mesh. Setelah itu dilakukan tahap deproteinasi, demineralisasi, depigmentasi, dan deasetilasi 3 tahap (Sanjaya dan Yuanita. 2007).

\section{Isolasi Kitosan}

Isolasi kitosan cangkang kepiting bakau mengacu pada Baharuddin S. dan Isnaeni D. (2020). yang mencakup proses deproteinasi, demineralisasi, depigmentasi, dan deasetilasi 3 tahap. Proses deproteinasi ini dilakukan pada suhu $60-80^{\circ} \mathrm{C}$ menggunakan $\mathrm{NaOH}$ I $\mathrm{M}$ dengan perbandingan serbuk cangkang kepiting bakau dengan $\mathrm{NaOH}=$ 70:700 (gram serbuk/ml $\mathrm{NaOH}$ ), selama I jam. Selanjutnya pada proses demineralisasi dari hasil deproteinasi pada suhu $60-80^{\circ} \mathrm{C}$ menggunakan $\mathrm{HCl}$ I M (dengan ratio 70:700 b/v), selama 3 jam. Pada proses depigmentasi, endapan hasil demineralisasi ditambahkan aseton kemudian di-bleaching (pemutihan) dengan 0,315\% $\mathrm{NaOCl}$ selama I jam pada suhu kamar. Proses terakhir adalah deasetilasi, dimana kitin yang telah dihasilkan pada proses depigmentasi dimasukkan ke dalam $\mathrm{NaOH}$ 60\% pada suhu $90-100^{\circ} \mathrm{C}$ sambil diaduk dengan kecepatan konstan selama 60 menit. Deasetilasi dilakukan sampai 3 kali pengulangan dengan variasi waktu reaksi yang berbeda. Hasil yang didapatkan yaitu berupa slurry yang dilanjutkan dengan penyaringan, endapan dicuci dengan aquadest lalu 
ditambah $\mathrm{HCl}$ encer agar $\mathrm{pH}$ netral kemudian dikeringkan dalam oven selama 24 jam. Hasil yang diperoleh merupakan senyawa kitosan.

\section{Pembuatan Konsentrasi Kitosan}

Pembuatan konsentrasi mengacu pada alur penelitian Suherman, et,al, (2018), namun konsentrasi kitosan yang digunakan pada pengujian efektivitas antijamur ini adalah 2, 3, 4, dan 5\%. Konsentrasi $2 \%$ dibuat dengan cara serbuk kitosan ditimbang sebanyak 2 gram, kemudian dimasukkan ke dalam labu ukur $100 \mathrm{ml}$, setelah itu ditambahkan dengan larutan asam asetat $\mathrm{I} \%$ sedikit demi sedikit hingga kitosan larut kemudian dicukupkan volumenya sampai tanda batas. Cara yang sama dilakukan untuk pembuatan konsentrasi kitosan 3, 4, dan 5\% yaitu dengan menimbang serbuk kitosan masing-masing sebanyak 3,4 , dan 5 g, selanjutnya dimasukkan ke dalam labu ukur $100 \mathrm{ml}$, ditambahkan larutan asam asetat I\% sedikit demi sedikit hingga kitosan larut kemudian dicukupkan volumenya sampai tanda batas.

\section{Pengujian Efektivitas Antijamur terhadap Epidermophyton floccosum dan Candida albicans}

Penentuan efektivitas antijamur dilakukan dengan metode apus Kirby-Bauer dengan menggunakan kertas cakram. Metode ini dilakukan dengan prosedur yaitu media agar SDA sebanyak 20 $\mathrm{ml}$ dituangkan ke dalam masing - masing cawan petri dan dibiarkan hingga padat, setelah itu ditambahkan 0,I $\mathrm{ml}$ inoculum Epidermophyton floccosum atau Candida albicans. Permukaan media diapus dengan cotton bud hingga tersebar merata. Setelah itu, diletakkan kertas cakram yang sebelumnya telah direndam dalam larutan kitosan cangkang kepiting bakau konsentrasi 2, 3, 4, dan 5\% dan kontrol negatif asam asetat $I \% \mathrm{v} / \mathrm{v}$ serta kontrol positif ketokonazol I\% menggunakan pinset. Masingmasing cawan petri ini diinkubasi pada $37^{\circ} \mathrm{C}$ dan pada hari ke-3 dan ke-4 pertumbuhan koloni diamati dan dihitung. Daerah hambatan yang terbentuk diukur dengan mistar geser kemudian dihitung ratarata dan deviasi standarnya (Karta \& Burhannuddin. 2017 ; Olioes. et.al. 2018).

\section{Analisis data}

Hasil pengukuran diameter hambatan pertumbuhan jamur, baik itu Epidermophyton floccosum maupun Candida albicans. dianalisis dengan metode analisis varian (oneway ANOVA) dan uji korelasi menggunakan bantuan program IBM SPSS Statistics versi 26.

\section{Hasil dan Pembahasan}

\section{Isolasi Kitosan cangkang kepiting bakau}

Kitosan merupakan polimer kationik yang bersifat nontoksik, dapat mengalami biodegradasi dan bersifat biokompatibel. Kitosan juga memiliki kegunaan yang sangat luas dalam kehidupan seharihari misalnya sebagai adsorben limbah logam berat dan zat warna, pengawet, antijamur, kosmetik, farmasi, flokulan, antikanker, dan antibakteri. Kitosan dapat aktif dan berinteraksi dengan sel, enzim atau matrik polimer yang bermuatan negatif (Kurniasih dan Kartika, 2009).

Kitosan mengandung tiga jenis gugus fungsi yaitu gugus amino, gugus hidroksil primer dan gugus hidroksil sekunder yang dapat memberi jembatan hidrogen secara intermolekuler atau intramolekuler. Adanya gugus fungsi ini menyebabkan kitosan mempunyai reaktifitas kimia yang tinggi sehingga menjadikannya sebagai polimer multifungsi (Riski, et.al, 2015). Kitosan yang diperoleh dari berbagai sumber memiliki struktur yang sama yaitu $\left.\left(\mathrm{C}_{6} \mathrm{H}_{\mathrm{IINO}}\right)_{4}\right)$, karena sampel mengalami proses yang sama yaitu demineralisasi, deproteinasi, dan deasetilasi sehingga senyawa lain yang menyusun sampel dapat dipisahkan sehingga terbentuk senyawa murni yang berupa kitosan (Sulistiyoningrum, et.al, 2013).

Senyawa kitosan dari cangkang kepiting bakau, didapatkan melalui beberapa tahapan isolasi yakni tahapan deproteinasi, demineralisasi, depigmentasi, dan deasetilasi 3 tahap. Pada proses deproteinasi berat awal sampel cangkang kepiting bakau sebesar $312,2 \mathrm{~g}$, setelah dikeringkan pada suhu $60^{\circ} \mathrm{C}$ selama 24 jam dan didinginkan dalam eksikator didapatkan berat akhir sebesar 207,4 g. Pada proses demineralisasi berat awal sampel 207,4 g yang merupakan berat dari hasil deproteinasi kemudian setelah dikeringkan selama 24 jam didapatkan berat akhir dari proses tersebut sebesar 96,9 g. Pada proses depigmentasi dengan berat awal 96,9 g yang merupakan berat dari hasil demineralisasi, didapatkan berat akhir setelah pengeringan sebesar 93,7 g dan pada tahap ini menghasilkan kitin. Proses akhir yaitu deasetilasi 3 tahap dengan berat awal sampel sebesar 93,2 g dan setelah dikeringkan selama 24 jam didapatkan berat akhir sebesar 46,3 g (senyawa kitosan). Hasil isolasi kitosan cangkang kepiting bakau dapat dilihat pada Tabel I. 
Tabel I. Hasil isolasi kitosan cangkang kepiting bakau (Scylla sp)

\begin{tabular}{cccc}
\hline Tahapan & $\begin{array}{c}\text { Berat } \\
\text { Awal } \\
(\mathrm{g})\end{array}$ & $\begin{array}{c}\text { Berat } \\
\text { Akhir } \\
(\mathrm{g})\end{array}$ & Keterangan \\
\hline Deproteinasi & 3I2,2 & 207,4 & $\begin{array}{c}\text { Uji Lanjut } \\
\text { Tahap 2 }\end{array}$ \\
\hline Demineralisasi & 207,4 & 96,9 & $\begin{array}{c}\text { Uji Lanjut } \\
\text { Tahap 3 }\end{array}$ \\
\hline Depigmentasi & 96,9 & 93,7 & $\begin{array}{c}\text { (Kitin) } \\
\text { Uji Lanjut } \\
\text { Tahap 4 }\end{array}$ \\
\hline $\begin{array}{c}\text { Deasetilasi 3 } \\
\text { tahap }\end{array}$ & 93,7 & 46,3 & Kitosan) \\
\hline
\end{tabular}

\section{Efektivitas antijamur kitosan cangkang kepiting bakau (Scylla sp)}

Pengujian efektivitas antijamur kitosan cangkang kepiting bakau dilakukan terhadap E. floccosum dan C. albicans Kedua jenis jamur tersebut telah melalui tahapan isolasi dengan pengenceran dan identifikasi secara makroskopis dan mikroskopis jamur.

\section{Pengujian terhadap E. floccosum}

Hasil pengujian efektivitas antijamur kitosan cangkang kepiting bakau terhadap pertumbuhan $E$. floccosum berupa diameter zona hambatan dengan masa inkubasi $3 \times 24$ jam pada suhu $37^{\circ} \mathrm{C}$ didapatkan zona hambat (rata-rata), untuk kontrol negatif sebesar $6,56 \pm 0$, II mm, $2 \% \mathrm{~b} / \mathrm{v}$ sebesar $10,23 \pm 0,46 \mathrm{~mm}, 3 \% \mathrm{~b} / \mathrm{v}$ sebesar $12,33 \pm 0,76 \mathrm{~mm}$, $4 \%$ sebesar $14,23 \pm 0,50 \mathrm{~mm}, 5 \% \mathrm{~b} / \mathrm{v}$ sebesar $16,23 \pm 0,64 \mathrm{~mm}$ dan kontrol positif didapatkan sebesar $21,66 \pm 0,40 \mathrm{~mm}$. Sedangkan pada masa inkubasi 4 × 24 jam pada suhu $37^{\circ} \mathrm{C}$ didapatkan zona hambat (rata-rata), untuk kontrol negatif sebesar $6,76 \pm 0,05 \mathrm{~mm}, 2 \% \mathrm{~b} / \mathrm{v}$ sebesar $1 \mathrm{I}, 16 \pm 0,6 \mathrm{I} \mathrm{mm}$, $3 \% \mathrm{~b} / \mathrm{v}$ sebesar $13,30 \pm 0,40 \mathrm{~mm}, 4 \%$ sebesar $15,30 \pm 0,20 \mathrm{~mm}, \quad 5 \% \mathrm{~b} / \mathrm{v}$ sebesar $17,56 \pm 0,75$ $\mathrm{mm}$ dan kontrol positif didapatkan sebesar $22,83 \pm 0,4 \mathrm{I} \mathrm{mm}$. Sebagaimana hasil pengujian tersebut dapat dilihat pada Tabel 2 dan gambar I.

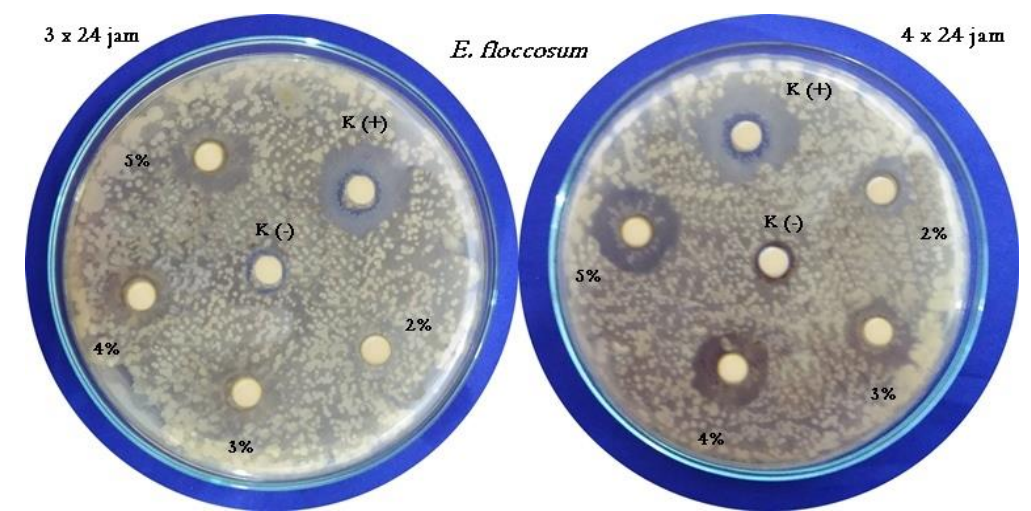

Gambar I. Diameter zona hambat kitosan cangkang kepiting bakau terhadap pertumbuhan E. floccosum masa inkubasi 3 × 24 jam dan 4 × 24 jam.

Keterangan : $\mathrm{K}(-)$ : kontrol negatif; $\mathrm{K}(+)$ : Kontrol positif; $2 \%, 3 \%, 4 \%$, dan 5\% masing-masing adalah konsentrasi kitosan cangkang kepiting bakau.

Tabel 2. Hasil pengujian efektivitas kitosan cangkang kepiting bakau terhadap pertumbuhan E. floccosum masa inkubasi 3 × 24 jam dan 4 × 24 jam

\begin{tabular}{ccccccc}
\hline \multirow{2}{*}{ Masa Inkubasi } & \multicolumn{7}{c}{ Rata - rata diameter zona hambatan (mm) } \\
\cline { 2 - 7 } & Kontrol $(-)$ & $\mathbf{2 \%} \mathrm{b} / \mathrm{v}$ & $\mathbf{3} \% \mathrm{~b} / \mathrm{v}$ & $\mathbf{4 \%} \mathrm{b} / \mathrm{v}$ & $\mathbf{5 \%} \mathrm{b} / \mathrm{v}$ & Kontrol (+) \\
\hline $3 \times 24 \mathrm{jam}$ & $6,56 \pm 0, \mathrm{I}$ & $\mathrm{I} 0,23 \pm 0,46$ & $\mathrm{I} 2,33 \pm 0,76$ & $\mathrm{I} 4,23 \pm 0,50$ & $\mathrm{I} 6,23 \pm 0,64$ & $2 \mathrm{I}, 66 \pm 0,40$ \\
\hline $4 \times 24 \mathrm{jam}$ & $6,76 \pm 0,05$ & $\mathrm{I} 1,16 \pm 0,6 \mathrm{I}$ & $\mathrm{I} 3,30 \pm 0,40$ & $\mathrm{I} 5,30 \pm 0,20$ & $\mathrm{I} 7,56 \pm 0,75$ & $22,83 \pm 0,4 \mathrm{I}$ \\
\hline
\end{tabular}

Hasil pengujian efektivitas antijamur kitosan cangkang kepiting bakau terhadap pertumbuhan Epidermophyton floccosum antara masa inkubasi 3 x 24 jam dan $4 \times 24$ jam jelas terlihat adanya peningkatan daya hambat yang terjadi, baik pada konsentrasi 2, 3, 4 dan 5\%. Hal ini tampak terlihat kitosan cangkang kepiting bakau efektif pada konsentrasi tersebut dan mampu penghambat pertumbuhan dari Epidermophyton floccosum, sebagaimana yang terlihat pada Gambar 2. 


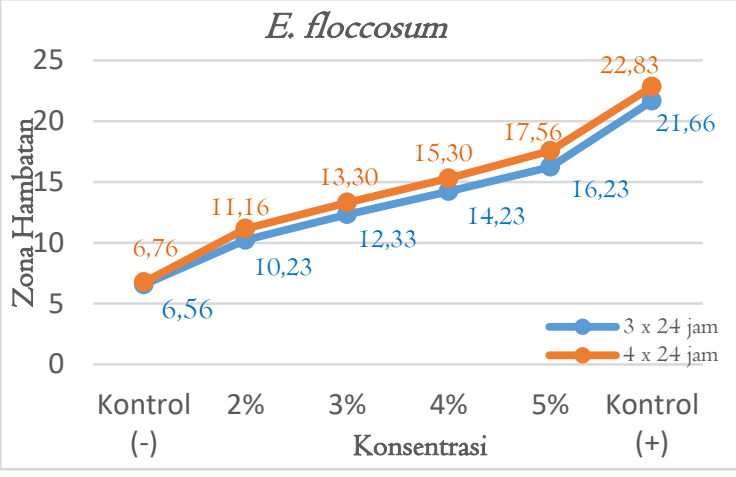

Gambar 2. Hubungan antara konsentrasi kitosan cangkang kepiting bakau dengan zona hambat yang

di hasilkan terhadap E. floccosum.

Pada hasil analisis data dengan menggunakan metode analisis varian (oneway ANOVA) diperoleh nilai Sig. $0.000(<0,05)$, baik pada masa inkubasi $3 \times 24$ jam maupun $4 \times 24$ jam, yang artinya adanya perbedaan yang bermakna antara variasi konsentrasi kitosan cangkang kepiting bakau dan zona hambat yang dihasilkan dari E. floccosum. Hal ini dapat dilihat pada data yang telah diuji, dimana semakin tinggi konsentrasi kitosan maka semakin besar pula zona hambat yang dihasilkan pada jamur uji $E$. floccosum.

\section{Pengujian terhadap C. albicans}

Hasil pengujian efektivitas antijamur kitosan cangkang kepiting bakau terhadap pertumbuhan $C$. albicans berupa diameter zona hambatan dengan masa inkubasi $3 \times 24$ jam pada suhu $37^{\circ} \mathrm{C}$ didapatkan zona hambat (rata-rata), untuk kontrol negatif sebesar $6,36 \pm 0$, II $\mathrm{mm}, 2 \% \mathrm{~b} / \mathrm{v}$ sebesar $8,50 \pm 0,00 \mathrm{~mm}, 3 \% \mathrm{~b} / \mathrm{v}$ sebesar $9,83 \pm 0,57 \mathrm{~mm}$,

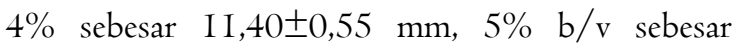
13,56 $\pm 0,49 \mathrm{~mm}$ dan kontrol positif didapatkan

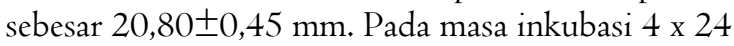
jam untuk kontrol negatif sebesar 6,50 $\pm 0,00 \mathrm{~mm}$, $2 \% \mathrm{~b} / \mathrm{v}$ sebesar $8,90 \pm 0,17 \mathrm{~mm}, 3 \% \mathrm{~b} / \mathrm{v}$ sebesar I0,00 $\pm 0,55 \mathrm{~mm}, 4 \%$ sebesar $12,00 \pm 0,30 \mathrm{~mm}, 5 \%$ $\mathrm{b} / \mathrm{v}$ sebesar $14,10 \pm 0,17 \mathrm{~mm}$ dan kontrol positif sebesar 21,56 $\pm 0,23 \mathrm{~mm}$. Hasil pengujian dapat dilihat pada Tabel 3 dan gambar 3 .

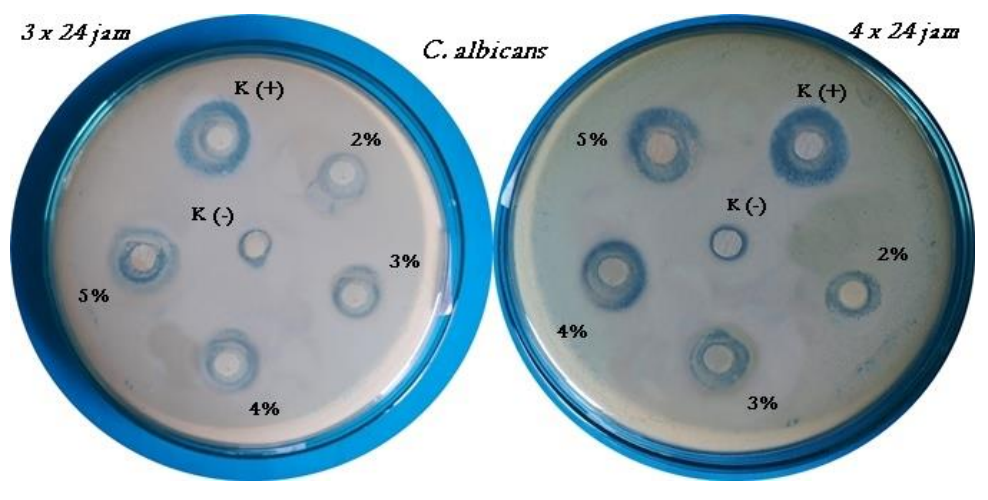

Gambar 3. Diameter zona hambat kitosan cangkang kepiting bakau terhadap pertumbuhan C. albicans masa inkubasi $3 \times 24$ jam dan 4 x 24 jam.

Keterangan : $\mathrm{K}(-)$ : kontrol negatif; $\mathrm{K}(+)$ : Kontrol positif; 2\%, 3\%, 4\%, dan 5\% masing-masing adalah konsentrasi kitosan cangkang kepiting bakau.

Tabel 3. Hasil pengujian efektivitas kitosan cangkang kepiting bakau terhadap pertumbuhan $C$. albicans masa inkubasi 3 × 24 jam dan 4 × 24 jam

\begin{tabular}{|c|c|c|c|c|c|c|}
\hline \multirow[b]{2}{*}{ Masa Inkubasi } & \multicolumn{5}{|c|}{ Rata - rata diameter zona hambatan ( $\mathrm{mm})$} & \multirow[b]{2}{*}{ Kontrol (+) } \\
\hline & Kontrol (-) & $2 \% \mathrm{~b} / \mathrm{v}$ & $3 \% \mathrm{~b} / \mathrm{v}$ & $4 \% \mathrm{~b} / \mathrm{v}$ & $5 \% \mathrm{~b} / \mathrm{v}$ & \\
\hline $3 \times 24$ jam & $6,36 \pm 0,11$ & $8,50 \pm 0,00$ & $9,83 \pm 0,57$ & 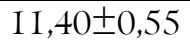 & $13,56 \pm 0,49$ & $20,80 \pm 0,45$ \\
\hline $4 \times 24$ jam & $6,50 \pm 0,00$ & $8,90 \pm 0,17$ & $10,00 \pm 0,55$ & $12,00 \pm 0,30$ & $\mathrm{I} 4, \mathrm{I} 0 \pm 0, \mathrm{I} 7$ & $21,56 \pm 0,23$ \\
\hline
\end{tabular}


Pengujian efektivitas antijamur kitosan cangkang kepiting bakau terhadap pertumbuhan Candida albicans antara masa inkubasi $3 \times 24$ jam dan $4 \times$ 24 jam juga terlihat adanya peningkatan daya hambat yang terjadi pada variasi konsentrasi. Namun diantara variasi konsentrasi kitosan dan diantara masa inkubasi terlihat peningkatan yang terjadi sangat kecil, hal ini kemungkinan disebabkan kitosan cangkang kepiting bakau pada konsentrasi tersebut hanya mampu bersifat bakteriostatik terhadap penghambatan Candida albicans, sebagaimana yang terlihat pada Gambar 4.

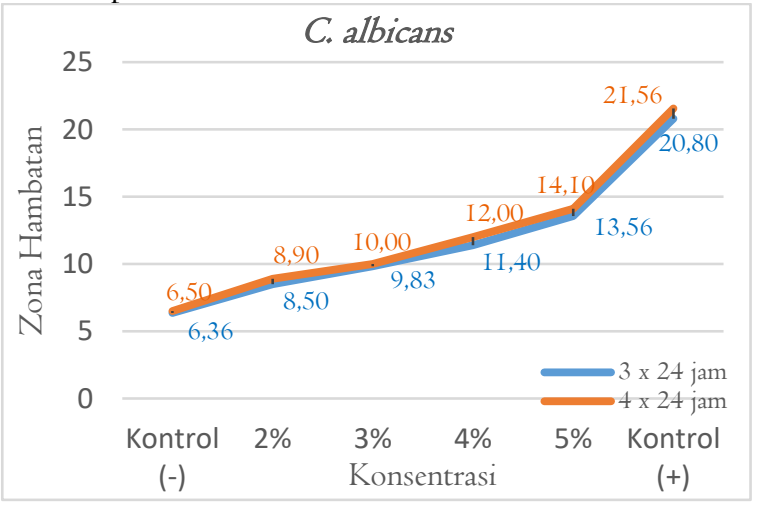

Gambar 4. Hubungan antara konsentrasi kitosan cangkang kepiting bakau dengan zona hambat yang di hasilkan terhadap $C$. albicans.

Hasil analisis data dengan menggunakan metode analisis varian (oneway ANOVA) diperoleh nilai Sig. $0.000(<0,05)$, baik pada masa inkubasi $4 \times 24$ jam maupun $4 \times 24$ jam, yang artinya terdapat perbedaan yang bermakna antara variasi konsentrasi dan zona hambat yang dihasilkan. Hal ini dapat dilihat pada data yang diuji, semakin tinggi konsentrasi kitosan cangkang kepiting bakau maka semakin besar pula zona hambat yang dihasilkan pada C. albicans.

Hasil yang diperoleh dari penelitian ini diketahui bahwa kitosan cangkang kepiting bakau (Scylla sp) efektif sebagai antijamur dalam menghambat pertumbuhan Epidermophyton floccosum dan Candida albicans, baik pada masa inkubasi $3 \times 24$ jam maupun 4 x 24 jam. Hal ini diduga kemungkinkan komponen - komponen kimia yang terdapat pada kitosan cangkang kepiting bakau seperti gugus fungsional amina $\left(-\mathrm{NH}_{2}\right)$ yang bermuatan positif serta memiliki pasangan elektron bebas dapat menghambat biosintesis trigliserida, fosfolipid dan aktivitas enzim oksidatif atau peroksidatif yang ada pada jamur. Selain itu kitosan sangat berpotensi untuk dijadikan sebagai bahan antimikroorganisme, karena mengandung enzim lysosim dan gugus aminopolysacharida yang dapat menghambat pertumbuhan mikroorganisme dan memiliki efisiensi daya hambat kitosan terhadap bakteri maupun jamur.

Variasi konsentrasi kitosan yang digunakan dalam pengujian efektivitas antijamur sangat berpengaruh terhadap daya hambat yang dihasilkan, dimana pada pengujian terhadap E. floccosum dengan masa inkubasi $3 \times 24$ jam dan $4 \times 24$ jam, hasil daya hambat yang dihasilkan pada konsentrasi 2, 3, dan $4 \%$ b/v masuk dalam klasifikasi respon hambatan sedang dan konsentrasi 5\% b/v masuk dalam kategori kuat. Sedangkan pengujian terhadap C. albicans dengan masa inkubasi $3 \times 24$ jam dan $4 \times$ 24 jam, daya hambat yang dihasilkan pada konsentrasi $2 \%$ dan $3 \%$ b/v masuk dalam kategori respon hambatan lemah serta $4 \%$ dan $5 \%$ b/v masuk dalam kategori respon pertumbuhan sedang. Menurut Alfiyah, et.al. (2015) dan Sudjarwo, et.al. (2019), penentuan kategori respon hambatan pertumbuhan jamur yaitu untuk diameter zona bening $<\mathrm{I} \mathrm{cm}$ memiliki respon hambatan pertumbuhan lemah, I - I,5 cm memiliki respon hambatan pertumbuhan sedang, I,6-2 cm memiliki respon hambatan pertumbuhan kuat dan $>2 \mathrm{~cm}$ memiliki respon hambatan pertumbuhan sangat kuat.

Perbedaan hasil daya hambat kitosan yang didapatkan pada pengujian terhadap E. floccosum maupun C. albicans baik itu $3 \times 24$ jam dan $4 \times 24$ jam masuk dalam kategori efektif, ini dapat dilihat pada hasil pengamatan pada konsentrasi 2, 3, 4 dan $5 \% \mathrm{~b} / \mathrm{v}$. Konsentrasi yang paling efektif diantara kedua pengujian tersebut adalah pada konsentrasi $5 \% \mathrm{~b} / \mathrm{v}$.

Pada penelitian ini juga digunakan kontrol negatif asam asetat $I \%$ dan kontrol positif Ketoconazole I\%. Penggunaan asam asetat I\% sebagai kontrol negatif karena asam asetat merupakan pelarut adsorben dari kitosan yang memiliki gugusgugus yang berikatan satu sama lain serta memiliki ion $\mathrm{H}$ - yang nantinya ikut berinteraksi dengan gugus amina $\left(-\mathrm{NH}_{2}\right)$ pada kitosan dalam menghambat pertumbuhan mikroorganisme dan juga asam asetat sebagai pelarut kitosan mampu memprotonasi gugus amina menjadi amino kationik $\left(-\mathrm{NH}_{3}+\right)$. Pada penelitian sebelumnya juga dijelaskan bahwa interaksi bahan antimikroorganisme dapat melalui interaksi ionik dan interaksi hidrofobik, namun karena kitosan tidak memiliki gugus alkil hidrofobik maka kemungkinan besar interaksi sifat antimikroorganisme polimer kitosan melalui interaksi ionik antara polikationik ammonium kuarterner kitosan dengan muatan ion negatif sel mikroorganisme seperti interaksi dengan menggunakan asam asetat (Baharuddin S. dan Isnaeni D., 2020). 
Penggunaan ketoconazole I\% sebagai kontrol positif karena ketokonazol adalah suatu obat anti jamur turunan imidazol yang memiliki aktivitas antifungi yang efektif terhadap dermatofit, ragi, seperti Tricophyton, Epidermophyton, Microsporum, Candida albicans (Katzung, 2004). Ketokonazole memiliki mekanisme kerja dengan mengganggu sintesis ergosterol yang merupakan unsur pokok yang spesifik pada membran sel jamur. Ketokonazol memiliki efek antijamur dengan spektrum luas dan efektivitas tinggi, berinteraksi dengan C-I4 alfa dimetilase (enzim 450 sitokom) untuk menghambat demetilasi lanosterol menjadi ergosterol. Sisi utama ketokonazol dapat menghambat sistem pernafasan pada $C$. albicans dengan cara menghambat aktivitas NADH oxidase pada tingkat mitokondria. Hal itu menyebabkan kerusakan membran secara langsung pada sel $C$. albicans. Dalam studi Hence, ketokonazol sebagai agen standart antifungi masih diteliti dalam melawan antimikroba yang lain (Shino, et.al, 2016).

\section{Simpulan dan Saran}

Kitosan cangkang kepiting bakau (Scylla sp) memiliki efektivitas sebagai antijamur terhadap pertumbuhan $E$. floccosum dan $C$. albicans dengan masa inkubasi 3 × 24 jam dan 4 × 24 jam pada suhu $37^{\circ} \mathrm{C}$. Konsentrasi yang paling efektif masing masing berada pada konsentrasi $5 \% \mathrm{~b} / \mathrm{v}$, dimana pada penghambatan E. floccosum sebesar

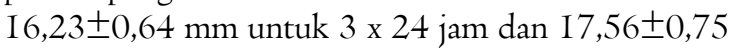
$\mathrm{mm}$ untuk $4 \times 24$ jam. Sedangkan pada penghambatan $C$. albicans untuk $3 \times 24$ jam sebesar $\mathrm{I} 3,56 \pm 0,49 \mathrm{~mm}$ dan $\mathrm{I} 4, \mathrm{I} 0 \pm 0, \mathrm{I} 7 \mathrm{~mm}$ untuk $4 \times 24$ jam.

Kitosan cangkang kepiting bakau (Scylla sp) efektif sebagai antijamur, maka disarankan untuk dilakukan penelitian lebih lanjut pada tingkat sediaan formula dengan kitosan sebagai zat aktif.

\section{Daftar Pustaka}

Aji A., Meriatna. (2012). Pembuatan kitosan dari limbah cangkang kepiting. Jurnal Teknologi Kimia Unimal. I(I), 79-90.

Alfiah R.R., Khotimah S., Turnip M. (2015). Efektivitas ekstrak metanol daun sembung rambat (Mikania micrantha Kunth) terhadap pertumbuhan jamur Candida albicans. Protobiont. 4 (I), 52-57.

Alioes Y., Kartika A., Zain E.A., Azzura V. (2018). Uji potensi antijamur Candida albicans ekstrak daun gelinggang (CASSIA ALATA L.) dibandingkan dengan sediaan daun sirih yang beredar di pasaran secara in vitro. Jurnal Kimia Riset, 3(2), I08-II5.
Azora G., Suwondo, Febrita E. (2013). Efektivitas chitosan kulit udang terhadap nilai gizi tahu sebagai sumber belajar biologi dengan model pembelajaran DI (Direct Intruction) pada konsep bioteknologi. Pekanbaru: Universitas Riau.

Baharuddin, S., \& Isnaeni, D. (2020). Isolasi dan uji aktivitas kitosan cangkang kerang bulu (Anadara inflata) sebagai antibakteri terhadap Staphylococcus epidermidis dan Escherichia coli. MPI (Media Pharmaceutica Indonesiana). 3(2), 60-69.

Damayanti W., Rochima E., Hasan Z. (2016). Aplikasi kitosan sebagai antibakteri pada filet patin selama penyimpanan suhu rendah. JPHPI (Jurnal Pengolahan Hasil Perikanan Indonesia). I9(3), 32I-328.

Karta I.W. dan Burhannuddin. (2017). Uji aktivitas antijamur ekstrak akar tanaman bama (Plumbago zeylanica) terhadap pertumbuhan jamur Trichophyton mentagrophytes penyebab kurap pada kulit, Jurnal Media Sains, I(I), 23-3I.

Katzung, B. G., (2004). Farmakologi Dasar dan Klinik: Basic and Clinical Pharmacology, Buku 3, Edisi 8. Bagian Farmakologi Fakultas Kedokteran Universitas Airlangga. Jakarta: Salemba Medika.

Kurniasih M. dan Kartika D., (2009). Aktivitas antibakteri kitosan terhadap bakteri $S$. aureus. Jurnal Molekul. 4(I), I-5.

Kusuma, S.H. (2016). Kemampuan kitin dari cangkang kepiting bakau (Scylla sp.) dalam menurunkan kadar kolesterol jeroan sapi. JIMPBio. I(I), I-IO.

Mawaddah F.S., Prasetyo J., \& Nurdin M. (2014). Pemanfaatan kitosan dan Trichoderma sp. Rifai. untuk mengendalikan penyakit antraknosa (Colletotrichum gloeosporioides Penz.) pada buah pisang cavendish. Jurnal Agrotek Tropika. 2(2), 215-219.

Midgley. Clason, Hay. (2008). Diagnosis Medical Mycologi. Penerbit Mosby Wolfe. London.

Mulyaningtyas D , Purwantisari S, Kusdiyantini E, Suryadi Y. (2016). Produksi kitosan secara enzimatik oleh Bacillus firmus E65 untuk pengendalian penyakit antraknosa pada buah mangga (Mangifera Indica L.). Jurnal Akademika Biologi (JAB). 5(4), 8-I7.

Pratiwi R. (2014). Manfaat kitin dan kitosan bagi kehidupan manusia, Jurnal Oseana, XXXIX(I), 35-43.

Ratnawati, Kardhinata, E.H., Sartini, (2016), Identifikasi dan penentuan jenis cendawan yang menginfeksi kulit pasien balita di rumah 
sakit umum pusat Haji Adam Malik Medan, BioLink (Jurnal Biologi Lingkungan, Industri \& Kesehatan). 2(2), 90-99.

Riski R. dan Sami F.J. (2015). Formulasi krim anti jerawat dari nanopartikel kitosan Cangkang Udang Windu (Penaeusmonodon). Jurnal Farmasi FIK UINAM. 3(4), I53-I6I.

Rochima E. (20I4). Kajian pemanfaatan limbah rajungan dan aplikasinya untuk bahan minuman berbasis kitosan. Jurnal Akuatika. 5(I), 7I-82.

Sanjaya I, Yuanita L. (2007). Adsorpsi Pb (II) oleh kitosan hasil isolasi kitin cangkang kepiting bakau (Scylla sp). Jurnal Ilmu Dasar, 8(I), 30-36.

Sudjarwo, G.W., Rosalia, M.S, Mahmiah. (2019). Uji aktivitas anti jamur nanopartikel kitosan terhadap jamur candida albicans secara in vitro, Prosiding, Seminar Nasional Kelautan $X I V$, Implementasi Hasil Riset Sumber Daya Laut dan Pesisir Dalam Peningkatan Daya Saing Indonesia, Surabaya, 50-57.

Suherman S., Latif M., Dewi S.T., (2018). Potensi kitosan kulit udang vannemei (Litopenaeus vannamei) sebagai antibakteri terhadap Staphylococccus epidermidis, Pseudomonas aeruginosa, Propionibacterium agnes, dan Escherichia coli dengan metode difusi cakram kertas. Media Farmasi. I4(I), I I6-I27.

Sulistiyoningrum RS, Suprijanto J, Sabdono A. (2013). Aktivitas anti bakteri kitosan dari cangkang kerang simping pada kondisi lingkungan yang berbeda: kajian pemanfaatan limbah kerang simping (Amusium sp.). Journal of marine research, 2(4), I I I-I I7.

Shino B., Peedikayil F.C., Jaiprakash S.R., Bijapur G.A., Kottayi S., Jose D. (2016). Comparison of antimicrobial activity of chlorhexidine, coconut oil, probiotics, and ketoconazole on Candida albicans isolated in children with early childhood caries: An in vitro study. Scientifica.

https://doi.org/IO.II55/2016/706I587

Trisnawati E, Andesti D, Saleh A. (2013). Pembuatan kitosan dari limbah cangkang kepiting sebagai bahan pengawet buah duku dengan variasi lama pengawetan, Jurnal Teknik Kimia, 2(19), I7- 